\title{
Dynamics and Conservation Management of a Wooded Landscape under High Herbivore Pressure
}

\author{
Adrian C. Newton, Elena Cantarello, Natalia Tejedor, and Gillian Myers \\ Centre for Conservation Ecology and Environmental Science, School of Applied Sciences, Bournemouth University, \\ Talbot Campus, Poole, Dorset BH12 5BB, UK
}

Correspondence should be addressed to Adrian C. Newton; anewton@bournemouth.ac.uk

Received 8 March 2013; Accepted 7 May 2013

Academic Editor: James T. Anderson

Copyright (C) 2013 Adrian C. Newton et al. This is an open access article distributed under the Creative Commons Attribution License, which permits unrestricted use, distribution, and reproduction in any medium, provided the original work is properly cited.

\begin{abstract}
We present the use of a spatially explicit model of woodland dynamics (LANDIS-II) to examine the impacts of herbivory in the New Forest National Park, UK, in relation to its management for biodiversity conservation. The model was parameterized using spatial data and the results of two field surveys and then was tested with results from a third survey. Field survey results indicated that regeneration by tree species was found to be widespread but to occur at low density, despite heavy browsing pressure. The model was found to accurately predict the abundance and richness of tree species. Over the duration of the simulations ( $300 \mathrm{yr}$ ), woodland area increased in all scenarios, with or without herbivory. While the increase in woodland area was most pronounced under a scenario of no herbivory, values increased by more than $70 \%$ even in the presence of heavy browsing pressure. Model projections provided little evidence for the conversion of woodland areas to either grassland or heathland; changes in woodland structure and composition were consistent with traditional successional theory. These results highlight the need for multiple types of intervention when managing successional landscape mosaics and demonstrate the value of landscape-scale modelling for evaluating the role of herbivory in conservation management.
\end{abstract}

\section{Introduction}

Identification of an appropriate approach for managing disturbance regimes represents one of the most significant challenges to conservation management. Disturbance can be considered as a cause of biodiversity loss, and in such cases management responses might be developed which reduce the frequency or intensity of disturbance events. However, many species are dependent on disturbance to complete one or more parts of their life cycle, and the persistence of such species within a given area will depend on maintenance of an appropriate disturbance regime $[1,2]$. This is particularly the case in successional habitats, such as heathland or grassland, which account for a significant proportion of areas of high conservation value in countries such as the UK [3]. Many management interventions, such as the cutting, burning, or grazing of vegetation, are designed to prevent the succession of such habitats to woodland. In order for effective management approaches to be developed, an understanding of the potential impacts of different disturbance regimes is required, including the interactions between different types of disturbance $[4,5]$.

To ensure that appropriate disturbance regimes are identified, tools are required that enable the ecological impacts of disturbance to be forecast. Such tools would inform the development of effective conservation management plans, by enabling the relative impacts of different management interventions to be explored. A range of approaches can potentially be used to predict the impacts of different forms of environmental change on biodiversity, including extrapolation, experiments, population models, expert opinion, and scenarios [6]. Given the fact that disturbance regimes are spatially heterogeneous and many of the processes influencing biodiversity have a spatial dimension [7], such tools should ideally be spatially explicit and support the identification of impacts at the landscape scale. In this context, we employ here a spatially explicit model of vegetation dynamics in order to examine the impacts of disturbance on a temperate wooded 
landscape of high biodiversity value. Although a number of process-based models of forest dynamics have been developed $[8,9]$, relatively few of these are spatially explicit, and few have been applied specifically to support conservation management [10]. Here we used the model LANDIS-II, which simulates the dynamics of wooded landscapes through the incorporation of a number of ecological processes including succession, disturbance and seed dispersal [11, 12]. LANDISII is based on an object-oriented modelling approach operating on raster maps, with each cell containing species, environment, disturbance, and harvesting information. LANDISII models have been widely applied in different parts of the world [12], increasingly in a conservation context [13]. For example, Newton et al. [4] explored the application of LANDIS-II to support systematic conservation planning in a dryland environment in Chile. Here we build on this previous research, by focusing explicitly on analyzing the impacts of herbivory as a form of disturbance.

In recent years, there has been a widespread increase in the use of large herbivores as a tool for conservation management, particularly in successional habitats. For example, grazing animals have recently been reintroduced to many lowland heathlands in the UK, despite the fact that evidence is lacking regarding their effectiveness in improving habitat quality [14]. Large herbivores are also central to the concept of "rewilding," which involves the reintroduction of populations of animals such as deer, cattle, and ponies to provide "naturalistic grazing" [15]. This approach has been advocated as the "optimal conservation strategy for the maintenance and restoration of biodiversity in Europe" $[15,16]$. Examples of large-scale naturalistic grazing initiatives include the Oostvaardersplassen [17] and Veluwezoom National Park [18] in the Netherlands and Knepp Estate, Wicken Fen, and Ennerdale in the UK [19]. These have parallels in the concept of "Pleistocene rewilding" currently being explored in both North and South America [20, 21].

The deployment of large herbivores as a conservation management approach has been supported by the theory developed by Vera [16], who hypothesized that in prehistory, the intense browsing pressure exerted by populations of large herbivores could have maintained extensive areas largely free of tree cover. Vera [16] also proposed that vegetation dynamics are cyclical under high herbivore pressure, owing to the prevention of tree regeneration under a forest canopy by herbivory. Instead, tree species would establish outside woodland through protection of seedlings from herbivory by spiny shrubs. Groves of trees would, therefore, become established within shrub vegetation, providing an example of tree regeneration by facilitation. Such groves would mature over time and eventually collapse, being replaced by grassland, which would subsequently be colonised by shrubs, reinitiating the vegetation cycle. The result would be a dynamic park-like mosaic of woodland and grassland, a pattern that would be created and maintained by populations of large wild herbivores [16].

While Vera's theory has had a major influence on conservation policy and management, it has also stimulated a great deal of debate among both researchers and management practitioners $[18,22,23]$. Much of this has focused on palaeoecological evidence regarding whether the early postglacial vegetation of northern Europe was densely forested, as traditionally believed, or more open in character. Relatively little research has been conducted on contemporary vegetation with the explicit objective of testing Vera's theory $[24,25]$. Much of this evidence is based on inference from existing vegetation structure and composition from which dynamics are inferred, as a form of space-for-time substitution. As noted by Fukami and Wardle [26], such approaches have a number of limitations, which can potentially be addressed by integrating survey data with modelling approaches, as explored here.

In this investigation, we employed LANDIS II supported by the collection and analysis of field survey data to examine the potential impact of populations of large herbivores on the spatial dynamics and composition of vegetation at the landscape scale. The overall aim of the research was to inform conservation management plans, both in relation to grazing and to other forms of disturbance undertaken as part of management, including the cutting and burning of vegetation. The research was conducted in the New Forest National Park, UK, an extensive area of seminatural vegetation of high biodiversity value that has been subjected to high herbivore pressure for many centuries $[27,28]$, and was cited by Vera [16] as evidence in support of his theory. Field surveys and modelling approaches were, therefore, used to test the following hypotheses, which were identified from Vera's theory [16, 24]: (i) within woodlands there is little or no regeneration of trees, even in canopy gaps, because of high herbivore pressure; (ii) regeneration occurs on the periphery of woodlands in blackthorn or holly scrub, which results in a concentric expansion of forest; (iii) woodland groves will tend to break up with maturity and be converted to either grassland or heathland; (iv) cyclic dynamics of vegetation at the site scale produces shifting mosaics of vegetation structural types at the landscape scale, dependent on the intensity, extent, and frequency of herbivory.

\section{Methods}

2.1. Study Area. The New Forest is situated on the south coast of England in the counties of Hampshire and Wiltshire (longitude from $1^{\circ} 17^{\prime} 59^{\prime \prime}$ to $1^{\circ} 48^{\prime} 8^{\prime \prime} \mathrm{W}$, latitude from $50^{\circ} 42^{\prime} 19^{\prime \prime}$ to $51^{\circ} 0^{\prime} 17^{\prime \prime} \mathrm{N}$ ). Its present character is strongly dependent on its history as a medieval hunting forest and the survival of a medieval commoning system. As a result, this landscape has developed under the influence of large, free-ranging herbivores, including deer as well as livestock, over a prolonged period [27]. The current research focused on the New Forest Special Area of Conservation (SAC), a Natura 2000 site, which forms the core of the National Park and is approximately 29,000 ha in area. The vegetation is a mosaic of pasture woodland, heathland, grassland, scrub, and mire communities. Woodlands occur both within inclosed areas that are legally designated for silviculture ("silvicultural inclosures") and in noninclosed areas ("open forest"). The difference between inclosed and noninclosed woodlands primarily reflects contrasting management histories, with 
timber extraction and plantation establishment largely restricted to the inclosed areas. While many inclosures have been fenced at some time in their past, recent management approaches have tended towards fence removal. In recent years, some 6000-7400 livestock, principally ponies and cattle, have been depastured in the New Forest [27, 28]. Five species of deer occur in the New Forest, with total numbers regulated at around 2000 animals through culling [28], although the actual number of deer present within the Forest at any one time is not known with precision.

2.2. Field Survey. A series of three field surveys were conducted over the period 2005-2010, as detailed below.

Survey 1 (woodland). Woodland structure and species composition were assessed throughout the study area. The sampling approach adopted the woodland units (WUs) used as a basis for monitoring habitat condition and included ancient pasture woodlands, exotic and native tree plantations, within both the open forest and the silvicultural inclosures. A total of 173 WUs were sampled, representing all areas classified as woodland. In each unit, a $50 \times 50 \mathrm{~m}$ plot was established and surveyed for woodland structure and composition. The plots were located randomly within the WUs using ArcGIS (v8.2 1999-2002, ESRI, California) and were located in the field using a Global Position System (GPS) device (Garmin III Plus, Garmin Europe Ltd., Southampton, UK). Within each plot, the number of individuals of each tree species was counted, and the diameter at breast height (dbh) of each tree $>10 \mathrm{~cm}$ dbh was measured using a diameter tape. The total number of saplings in the plot was measured, with saplings defined as trees $<10 \mathrm{~cm}$ dbh but $>1.3 \mathrm{~m}$ height, and also the total number of tree seedlings (i.e., individuals $<1.3 \mathrm{~m}$ height) of each species was recorded in a $10 \mathrm{~m} \times 10 \mathrm{~m}$ subplot. Canopy closure (sensu Newton [10]) was estimated in the centre of each plot, using a spherical densiometer (Forestry Suppliers Inc., Missouri, USA). In each plot, a series of ten variables were assessed by visual observation to provide a measure of browsing pressure, following Reimoser et al. [29]. The categorization of browsing pressure, based on these assessments, was derived from the same source [29] (see Appendix 1 (in Supplementary Material available online at http://dx.doi.org/10.1155/2013/273948/)). Trees of each species were also cored for age determination in the laboratory.

Survey 2 (heathland and grassland). In order to parameterise LANDIS-II for the entire study area, information was also required on the structure and composition of vegetation in grassland and heathland areas. In total, 50 grassland and heathland units (GHUs) were surveyed, including 99\% units $>50$ ha in size and $92 \%$ units $>10$ ha in size (those representing road verges being excluded). In each unit, a $50 \times 50 \mathrm{~m}$ plot was located randomly and surveyed as described in Survey 1. The relationship between age and stem diameter in Ulex europea (gorse) and in the ericaceous shrubs Calluna vulgaris (common heather), Erica cinerea (bell heather), and Erica tetralix (cross-leaved heath) were determined by measuring the stem diameter of 20 individuals of each species at the base using a digital calliper. Increment cores (or stem sections for the ericaceous shrubs) were taken at the stem base for age determination in the laboratory.

Survey 3 (woodland expansion). A third field survey ("Survey 3") was undertaken to provide an independent data set with which to test the LANDIS-II model. For this purpose, field data were required for sites where woodland expansion is occurring outside the boundary of the WUs and were, therefore, not included in model parameterization. Thirty locations were identified based on aerial photographs and field observations. Sites for survey were identified by selecting areas of woodland expansion greater than $50 \times 50 \mathrm{~m}$ in area, lying outside but adjacent to WU boundaries. At each location, a $50 \mathrm{~m} \times 50 \mathrm{~m}$ plot was established and surveyed as described for Survey 1. In addition, a record was made of whether individual tree seedlings were associated with protective shrub cover or not.

\subsection{Model Parameterization and Calibration. In LANDIS} II, tree species are simulated as the presence or absence of species age cohorts in each cell, at a time step specified by the user. A detailed description of the LANDIS-II model is provided elsewhere ([12], http://www.landis-ii.org/). The inputs required by the model include a land type or ecoregion map, which describes the ecological conditions influencing tree establishment, and an initial communities map, which describes the distribution and age of cohorts of each species at year 0 of the simulations. The initial communities map was produced using the WUs defined by Natural England and the field data collected in Surveys 1 and 2.

The ecoregion map was produced by defining 30 ecoregions on the basis of elevation and soil type. This was achieved by mapping combinations of six elevation classes (0-29, 30-59, 60-89, 90-119, and $\geq 120 \mathrm{~m}$ a.s.l.) and eight soil types that occur in the study area, at $50 \mathrm{~m}$ resolution. Ecoregions were mapped by identifying combinations of elevation classes and soil type. Elevation data were derived from OS Land-Form PROFILE DTM 1:10000 using DIGIMAP (http://edina.ac.uk/digimap/) and converted to raster format. Soil data were obtained from (NATMAP National Soil Map; National Soil Resources Institute (NSRI), Silsoe, Bedfordshire, UK). A land cover map obtained from the Hampshire Biodiversity Information Centre (HBIC), together with a map of water bodies obtained from DIGIMAP, was used to identify areas of water, sea shore habitats, urban development, quarries, and arable or horticultural land, which were excluded from all model simulations. All maps were produced and manipulated using ArcGIS 9.2 (1999-2006 ESRI Inc., Redlands, California) and Idrisi Andes (Clark Labs, Clark University, Worcester, MA, USA) projected using British National Grid. The maps were $800 \times 800$ pixels in area.

In LANDIS-II, forest succession is a competitive process governed by the probability of establishment in different ecoregions and the life history characteristics of each species. The life history characteristics of the 37 woody species encountered in the field survey (Table 1) were obtained from the scientific literature, supplemented by field observations. In LANDIS-II, forest succession interacts with several 
TABLE 1: Ecological characteristics for the tree and shrub species encountered in the New Forest study area, which were included in model simulations.

\begin{tabular}{|c|c|c|c|c|c|c|c|c|c|c|c|c|c|c|c|}
\hline \multirow{2}{*}{ Name } & \multirow{2}{*}{ Long } & \multirow{2}{*}{ Mat } & \multirow{2}{*}{ ShT } & \multirow{2}{*}{ FiT } & \multirow{2}{*}{ EffSD } & \multirow{2}{*}{$\operatorname{MaxSD}$} & \multirow{2}{*}{ VRP } & \multirow{2}{*}{ Min VRP } & \multirow{2}{*}{ Max VRP } & \multirow{2}{*}{ P-FiR } & \multicolumn{5}{|c|}{$\mathrm{BP}$} \\
\hline & & & & & & & & & & & DB1 & DB2 & DB3 & $\mathrm{PB}$ & DB1 \\
\hline Abies grandis & 300 & 20 & 4 & 1 & 60 & 120 & 0 & 0 & 0 & None & $\mathrm{Y}$ & & & & $\mathrm{Y}$ \\
\hline Acer campestre & 200 & 10 & 3 & 1 & 80 & 120 & 1 & 10 & 120 & None & & $\mathrm{Y}$ & & $\mathrm{Y}$ & \\
\hline Acer pseudoplatanus & 150 & 12 & 4 & 1 & 120 & 400 & 1 & 10 & 100 & None & $\mathrm{Y}$ & & & $\mathrm{Y}$ & $\mathrm{Y}$ \\
\hline Alnus glutinosa & 250 & 12 & 3 & 1 & 120 & 200 & 1 & 10 & 200 & None & & $\mathrm{Y}$ & & $\mathrm{Y}$ & \\
\hline Betula pendula & 160 & 18 & 2 & 1 & 200 & 1600 & 1 & 10 & 120 & None & & $\mathrm{Y}$ & & $\mathrm{Y}$ & \\
\hline Calluna vulgaris & 30 & 1 & 1 & 1 & 100 & 250 & 1 & 0 & 30 & Resprout & $\mathrm{Y}$ & & & $\mathrm{Y}$ & $\mathrm{Y}$ \\
\hline Carpinus betulus & 250 & 20 & 4 & 1 & 90 & 130 & 1 & 10 & 150 & None & & $\mathrm{Y}$ & & $\mathrm{Y}$ & \\
\hline Castanea sativa & 300 & 35 & 3 & 1 & 300 & 700 & 1 & 10 & 250 & None & & $\mathrm{Y}$ & & $\mathrm{Y}$ & \\
\hline Chamaecyparis lawsoniana & 200 & 20 & 3 & 1 & 80 & 120 & 0 & 0 & 0 & None & & & $\mathrm{Y}$ & & \\
\hline Corylus avellana & 80 & 10 & 4 & 1 & 300 & 700 & 1 & 10 & 80 & None & $\mathrm{Y}$ & & & $\mathrm{Y}$ & $\mathrm{Y}$ \\
\hline Crataegus monogyna & 150 & 4 & 2 & 1 & 300 & 700 & 1 & 10 & 100 & None & & & & & \\
\hline Fagus sylvatica & 500 & 55 & 5 & 1 & 300 & 700 & 1 & 10 & 300 & None & & $\mathrm{Y}$ & & $\mathrm{Y}$ & \\
\hline Frangula alnus & 80 & 3 & 2 & 2 & 300 & 700 & 1 & 10 & 30 & None & $\mathrm{Y}$ & & & $\mathrm{Y}$ & $\mathrm{Y}$ \\
\hline Fraxinus excelsior & 200 & 17 & 3 & 1 & 90 & 120 & 1 & 10 & 200 & None & $\mathrm{Y}$ & & & $\mathrm{Y}$ & $\mathrm{Y}$ \\
\hline Ilex aquifolium & 300 & 10 & 3 & 1 & 300 & 700 & 1 & 10 & 300 & None & & & $\mathrm{Y}$ & $\mathrm{Y}$ & \\
\hline Larix decidua & 200 & 20 & 2 & 1 & 120 & 400 & 0 & 0 & 0 & None & & $\mathrm{Y}$ & & & \\
\hline Malus sylvestris & 130 & 8 & 2 & 1 & 300 & 700 & 1 & 10 & 100 & None & & $\mathrm{Y}$ & & $\mathrm{Y}$ & \\
\hline Picea abies & 300 & 40 & 2 & 1 & 100 & 120 & 0 & 0 & 0 & None & & & $\mathrm{Y}$ & & \\
\hline Picea sitchensis & 300 & 22 & 2 & 1 & 100 & 120 & 0 & 0 & 0 & None & & & $\mathrm{Y}$ & & \\
\hline Pinus nigra & 350 & 22 & 2 & 1 & 100 & 150 & 0 & 0 & 0 & None & & & $\mathrm{Y}$ & & \\
\hline Pinus ponderosa & 300 & 7 & 2 & 1 & 100 & 150 & 0 & 0 & 0 & None & & & $\mathrm{Y}$ & & \\
\hline Pinus sylvestris & 300 & 12 & 2 & 1 & 100 & 1000 & 0 & 0 & 0 & None & & $\mathrm{Y}$ & & & \\
\hline Populus alba & 250 & 7 & 2 & 1 & 500 & 1600 & 1 & 10 & 250 & None & $\mathrm{Y}$ & & & $\mathrm{Y}$ & $\mathrm{Y}$ \\
\hline Prunus spinosa & 60 & 4 & 2 & 1 & 300 & 700 & 1 & 10 & 60 & None & & & & & \\
\hline Pseudotsuga menziesii & 400 & 12 & 2 & 3 & 120 & 380 & 0 & 0 & 0 & None & & $\mathrm{Y}$ & & & \\
\hline Quercus robur & 500 & 60 & 2 & 1 & 300 & 700 & 1 & 10 & 400 & None & $\mathrm{Y}$ & & & $\mathrm{Y}$ & $\mathrm{Y}$ \\
\hline Quercus rubra & 200 & 22 & 4 & 3 & 300 & 700 & 0 & 0 & 0 & None & $\mathrm{Y}$ & & & $\mathrm{Y}$ & $\mathrm{Y}$ \\
\hline Salix cinerea & 90 & 35 & 2 & 1 & 1000 & 1600 & 1 & 10 & 70 & None & $\mathrm{Y}$ & & & $\mathrm{Y}$ & $\mathrm{Y}$ \\
\hline Sorbus aria & 150 & 6 & 2 & 1 & 300 & 700 & 0 & 0 & 0 & None & $\mathrm{Y}$ & & & $\mathrm{Y}$ & $\mathrm{Y}$ \\
\hline Sorbus aucuparia & 100 & 15 & 2 & 1 & 300 & 700 & 1 & 10 & 100 & None & $\mathrm{Y}$ & & & $\mathrm{Y}$ & $\mathrm{Y}$ \\
\hline Sorbus torminalis & 100 & 13 & 4 & 1 & 300 & 700 & 1 & 10 & 100 & None & $\mathrm{Y}$ & & & $\mathrm{Y}$ & $\mathrm{Y}$ \\
\hline Taxus baccata & 3000 & 20 & 4 & 1 & 300 & 700 & 0 & 0 & 0 & None & & & $\mathrm{Y}$ & & \\
\hline Tsuga heterophylla & 400 & 15 & 2 & 1 & 120 & 160 & 0 & 0 & 0 & None & & & $\mathrm{Y}$ & & \\
\hline Ulex europea & 40 & 2 & 1 & 1 & 1 & 700 & 1 & 0 & 40 & Resprout & & & & & \\
\hline Viburnum opulus & 50 & 5 & 2 & 1 & 300 & 700 & 1 & 10 & 40 & None & $\mathrm{Y}$ & & & $\mathrm{Y}$ & $\mathrm{Y}$ \\
\hline
\end{tabular}

Long: longevity (years); Mat: age of sexual maturity (years); ShT: shade tolerance (1-5); FiT: fire tolerance (1-5); EffSD: effective seed dispersal distance (m); MaxSD: maximum seed dispersal distance (m); VRP: vegetative reproduction probability (0-1); MinVRP: minimum age of vegetative reproduction (years); MaxVRP: maximum age of vegetative reproduction (years); P-FiR: postfire regeneration form (none, resprouting, or serotiny). Principal literature sources included [39, 40,51, 53-58]. BP refers to browsing preference; in these simulations, those species indicated with a "Y" were considered to be of either high (DB1), moderate (DB2), or low (DB3) preference by deer. PB indicates whether the species were browsed by ponies (Y) or not in the scenarios where browsing was included. These groups were identified by reference to the available literature [14, 32, 59-65].

spatial components (i.e., seed dispersal, fire, and harvesting disturbances). The establishment probability of each tree species in each ecoregion was derived from the Ecological Site Classification (ESC) decision-support system developed for British forests (v1.7; [30]; see also Appendix 1). Model calibration was performed by examining the spatial dynamics of each species in repeated simulations over a 1000 year interval, with browsing and fire disturbances approximating current values, and comparing results with field observations.

The LANDIS-II Base Fire v2.1 extension was used to explore fire dynamics. Calibration involves the systematic adjustment of fire model parameters over multiple simulations, until the average area burned per time interval is within a small percentage of the target value [31]. A fire 
ecoregion map was created by dividing the study area into 11 units, coinciding with management units subjected to rotational heathland burning as part of current management practices [27]. On average, around 400 ha of heathland are burned annually. Maximum fire size was set to 10 ha to be consistent with current management practice (Mr. David Morris, Forestry Commission, personal communication). Fire ignition probabilities were varied proportionally to the area of each management unit, so that the proportion of each management unit that burned in a given year was roughly equal. Fire "spread age" (which represents the expected fire rotation period) was set to 15 years, to coincide with the rotation period used in current management practice. Fire ignition probabilities were adjusted through multiple simulations to achieve an expected average annual burned area close to 400 ha. Calibration was completed when a value within $1 \%$ of this total was obtained.

The harvest module of LANDIS-II (Base Harvest extension v1.2) was used to simulate the impacts of browsing by livestock and deer. Browsing was modelled by the removal of the youngest cohort (1-10 years old) of plants. Browsing was implemented using the "Patch Cutting" option in Base Harvest, such that randomly selected groups of sites within a stand were harvested. Browsing pressure was distributed evenly among different vegetation types. The percentage of cells with a stand to be harvested as a result of deer browsing was set at $90 \%$ for the most palatable species, $80 \%$ for intermediate species, and $70 \%$ for the least palatable species (Table 1). For browsing by ponies, the percentage value was $50 \%$. The size of the patches that were harvested varied according to the typical home range size of the animals concerned and was set at 80 ha for deer and 150 ha for ponies [32]. Base Harvest was calibrated through a sensitivity analysis, which was performed by systematically varying both the percentage of cells within a forest stand to be harvested and the patch size. In order to be consistent with field observations, the harvesting parameters were adjusted such that the model projected $95 \%$ mortality of birch in the open forest (i.e., in areas outside woodland) as a result of browsing. These same parameter values produced a $66 \%$ reduction in frequency of beech within woodland areas.

2.4. Scenarios. Once model calibration was completed, final values of the model parameters were used in a series of modelled scenarios. Simulations were conducted for 300 years. Five replicated simulations (with varying random number seed) were performed for each scenario. Two forms of disturbances were explored in the scenarios: the mortality of young trees caused by the activities of large mammals ("browsing") and the effects of burning ("fire"). The time steps were set at 10 years for tree succession, 10 years for fire disturbance, and 1 year for browsing. The scenarios were defined as follows: scenario 1, no disturbance (neither fire nor browsing); scenario 2, browsing only; scenario 3, fire only; scenario 4, fire plus browsing; scenario 5, browsing, fire, and protection from herbivory by presence of spiny shrubs, where mortality of trees as a result of browsing was set to zero if either of the species Crataegus monogyna (hawthorn), Prunus spinosa (blackthorn), or Ulex europea (gorse) was present of ages 5-100 years old within at least $50 \%$ of the cells in the stand.

2.5. Data Analysis. In order to test the factors influencing regeneration, the density of seedlings and saplings of each native woody species recorded in each plot in Survey 1 was correlated with (i) the extent of canopy closure and (ii) the index of browsing pressure. Spearman's rank correlation analyses were performed using SPSS (SPSS Inc., Chicago, USA), as the data were not normally distributed, as indicated by the Shapiro-Wilk tests. The data obtained in Survey 1 were divided into two groups, "inclosed" and "noninclosed," based on whether or not the survey plots were located within silvicultural inclosures, as these two groups have been subjected to different management histories. Stand structure was analysed by calculating size-frequency distributions for each tree species based on the number of individuals within each stem diameter category, pooling survey plots within each group. Statistical differences in stem densities and canopy closure between inclosed and noninclosed plots were examined using Mann-Whitney $U$ tests performed using SPSS. The alpha level of statistical tests was set at 0.05 .

Field data from Survey 3, which were independent of those used in model parameterisation, were used to test model predictions. The model was tested by analysing the relationship between the number of survey plots in which each tree species was predicted to occur using the model and the number of plots in which each species was recorded in the field survey. This relationship was tested by linear regression using SPSS v.16 (SPSS Inc., Chicago, USA).

The Age Cohort Statistics v1.0 extension of LANDIS-II was used to produce outputs of (i) minimum and maximum age across all species in each pixel, and (ii) the presence of selected species in each pixel under each of the scenarios. The following species were selected for analysis on the basis of their ecological importance within the study area: Betula pendula (birch), Fagus sylvatica (beech), Ilex aquifolium (holly), Pinus sylvestris (Scots pine), and Quercus robur (oak). The LANDIS-II outputs consist of raster maps produced for each time step of the simulation (10 years). The total extent of woodland was calculated as the total number of pixels within which one or more of these five species was present, as an adult tree $\geq 10$ years old.

\section{Results}

3.1. Survey 1. In total, 70 plots were established in noninclosed woodland units and 103 in inclosed units. The plots were predominantly located in woodland stands with high canopy closure, with $79 \%$ plots in both inclosed and noninclosed units, demonstrating canopy closure values $>80 \%$ (Figure 1). Median values did not differ significantly between the two unit types $(P=0.193$, Mann-Whitney $U$ test $)$, with values recorded of $93.5 \%$ and $91.9 \%$ for inclosed and noninclosed units respectively. In terms of stem densities of mature trees ( $>10 \mathrm{~cm} \mathrm{dbh})$, the most abundant species in the noninclosed stands were oak, beech, birch, holly, and Scots pine, each with mean values of $>11$ ind $\cdot \mathrm{ha}^{-1}$ (Appendix 1). 


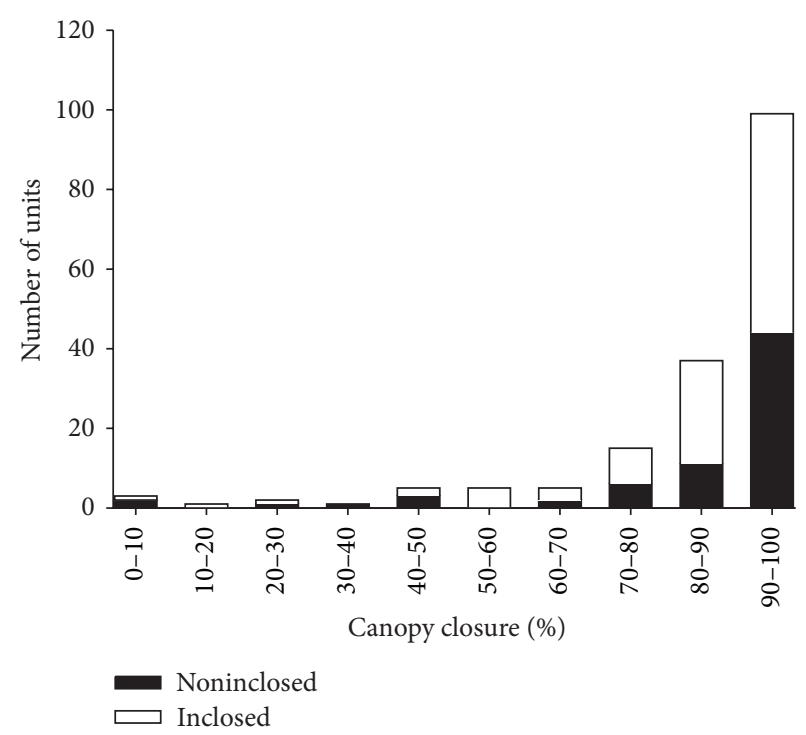

(a)

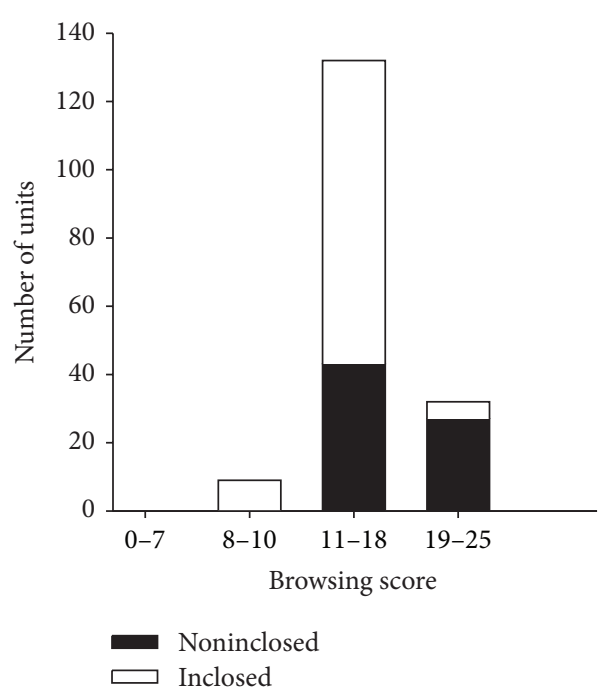

(b)

Figure 1: Measurements of (a) canopy closure and (b) browsing pressure in the woodlands of the New Forest, as assessed in Survey 1 (see text). Inclosed areas are those designated for silvicultural intervention. Total browsing scores of $<7$ were associated with light, $8-10$ moderate, 11-18 heavy, and 19-25 very heavy browsing pressure, respectively (following [29]).

In the inclosures, a number of nonnative coniferous species were also abundant, including Picea abies (Norway spruce), Pinus nigra (European black pine), and Pseudotsuga menziesii (Douglas fir), each with mean densities of $>16$ ind $\cdot \mathrm{ha}^{-1}$ (Appendix 1).

Individual species displayed a variety of different structural patterns (Figure 2). Stand structure of beech was characterised by an "inverse-J" shape, with relatively large numbers of trees in smaller-diameter size classes and with decreasing frequency as the size class increased. This pattern was evident in both noninclosed and inclosed stands and implied continual recruitment in both woodland types. Inverse-J sizefrequency distributions were also encountered in holly, where stem densities were substantially higher in noninclosed than in inclosed stands and in birch, particularly in inclosed stands (Figure 2). Other species characterised by inverse-J stand structures included hawthorn, Fraxinus excelsior (ash), and Salix cinerea (grey willow), which like holly, occurred at much higher densities in noninclosed than in inclosed stands.

In contrast, a number of species were characterised by unimodal distributions, with relatively low numbers of individuals in the smaller-diameter size classes. For example, highest stem densities of oak were recorded in the $40-45 \mathrm{~cm}$ size class in noninclosed sites and in the $20-25 \mathrm{~cm}$ size class in inclosed sites (Figure 2). Mean sapling densities of this species $(<10 \mathrm{~cm} \mathrm{dbh})$ were 4.4 and $1.7 \mathrm{ind} \cdot \mathrm{ha}^{-1}$ in noninclosed and inclosed units, respectively. Scots pine also displayed a unimodal size distribution, with highest values recorded in the $20-25 \mathrm{~cm}$ size class in inclosed forest; substantially lower values were found in the noninclosed sites. A similar stand structure was displayed by Alnus glutinosa (alder).
Of the 38 woody species recorded in the survey with stems $>10 \mathrm{~cm} \mathrm{dbh}, 34(89 \%)$ were also recorded as a sapling and $31(82 \%)$ as a seedling. For most species, seedling densities did not differ significantly between inclosed and noninclosed units (Figure 3 ). The regeneration of most woody species was not related to the extent of canopy closure, when analysed by correlation. In the case of sapling density, a statistically significant relationship with canopy closure was only recorded in one species, namely, alder $(r=-0.15$, $P=0.045)$. In the case of seedlings, statistically significant relationships with canopy closure were recorded in only two species, beech $(r=0.15, P=0.048)$ and holly $(r=0.016$, $P=0.032$ ).

Results of the browsing survey (Figure 1(b)) indicated that all of the inclosed plots were characterised by at least moderate browsing pressure (score 8-10), whereas all of the noninclosed plots were associated with at least heavy browsing pressure (score $\geq 11$ ). Most plots (61\% noninclosed and $86 \%$ inclosed) were classified as heavy browsing (score 11-18), with very heavy browsing (score 19-25) proportionally being more evident in the noninclosed than in the inclosed plots (39\% and $5 \%$ of plots resp.). Median browsing score was significantly higher in the noninclosed than in the inclosed plots (values of 18 and 14, resp.; $P<0.001$, MannWhitney $U$ test). Browsing impact score was not significantly related to canopy closure $(r=-0.016, P=0.837)$. When sapling density was correlated with browsing impact score, significant relationships were found only in holly $(r=0.31$, $P<0.001)$, birch $(r=-0.25, P=0.001)$, Frangula alnus ( $r=0.18, P=0.019)$, $P$. sylvestris $(r=-0.21, P=0.005)$, and Prunus spinosa (alder buckthorn) $(r=0.21, P=0.004)$. In the case of seedling density, significant relationships were 


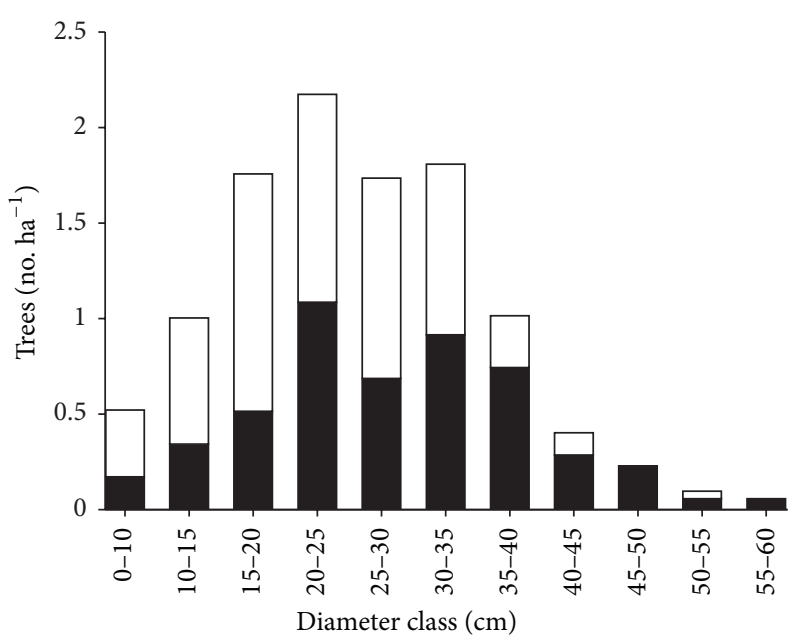

(a)

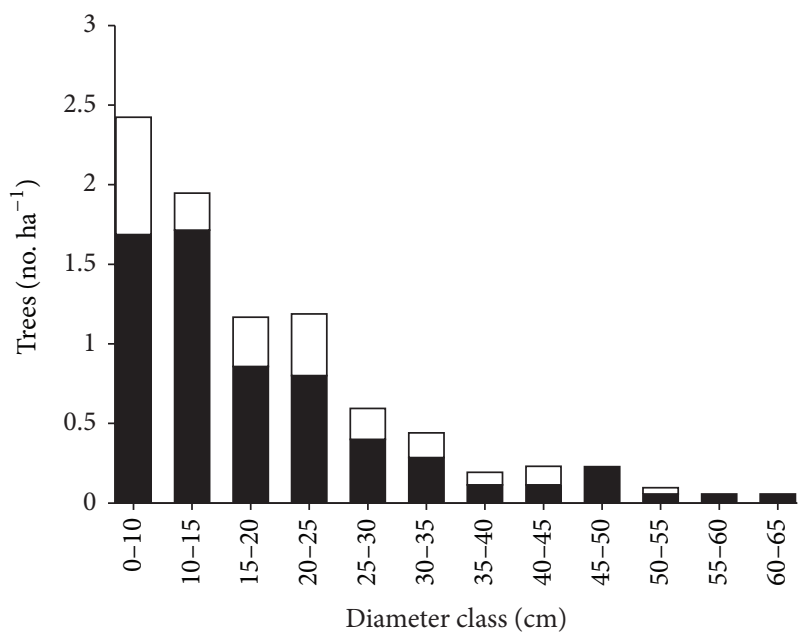

(c)

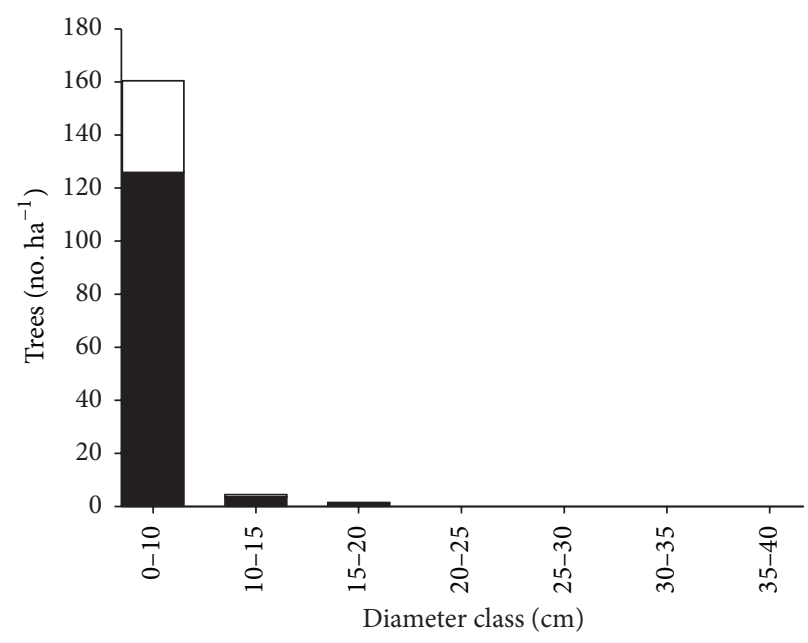

(b)

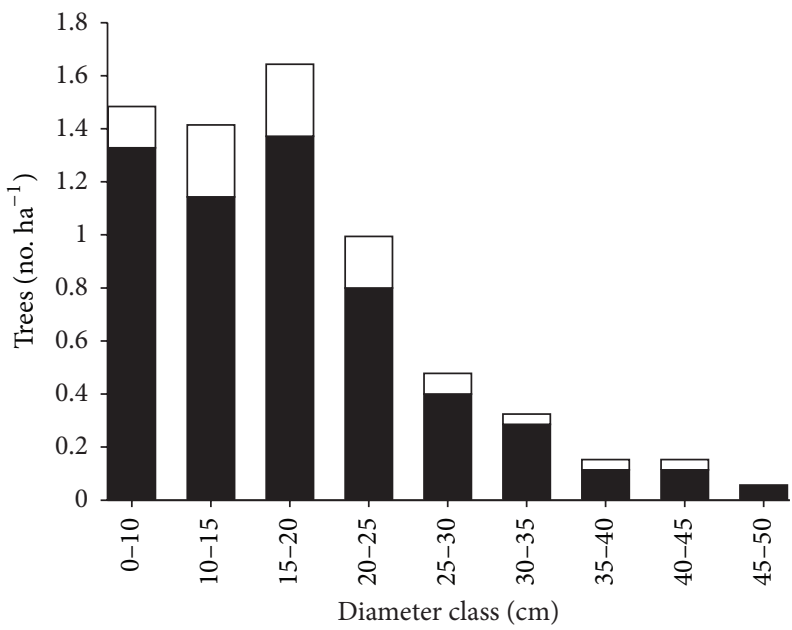

(d)

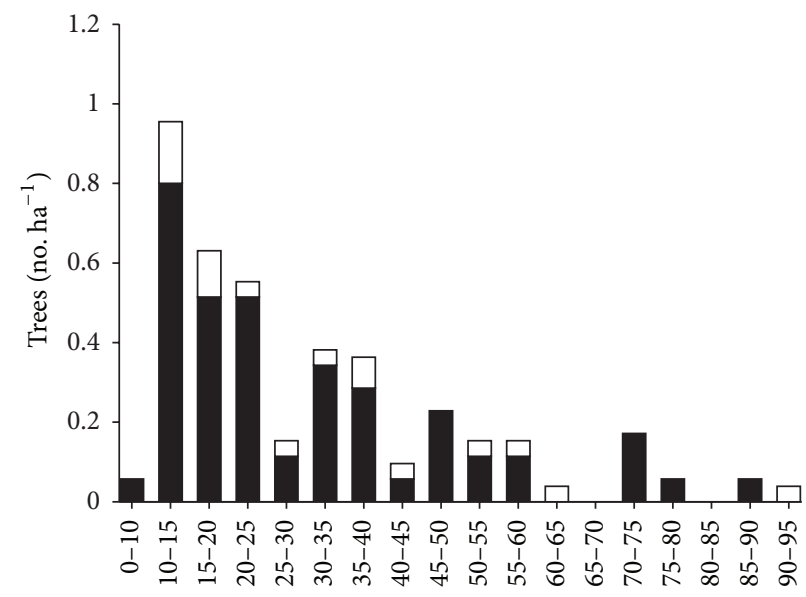

Diameter class $(\mathrm{cm})$

(e)

FIGURE 2: Stand structure of the New Forest woodlands, illustrated as the size frequency distributions of selected tree species, assessed in Survey 1 (see text). (a) Betula pendula; (b) Fagus sylvatica; (c) Ilex aquifolium; (d) Pinus sylvestris; (e) Quercus robur. Filled bars, noninclosed units; open bars, inclosed units. 


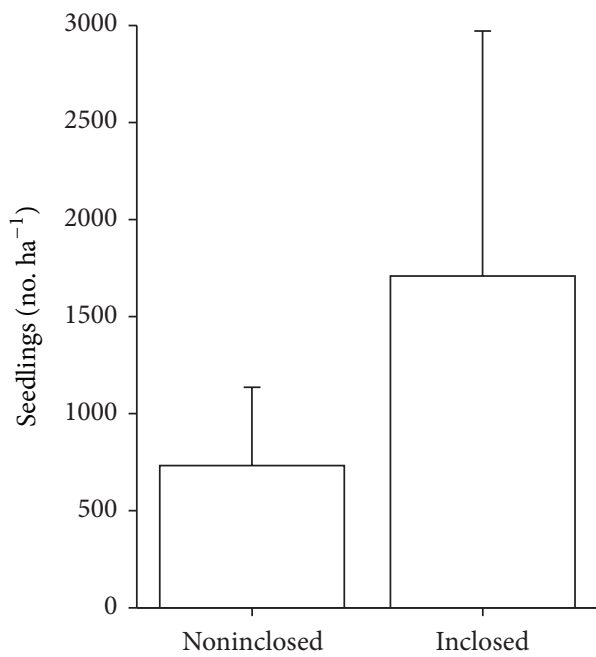

(a)

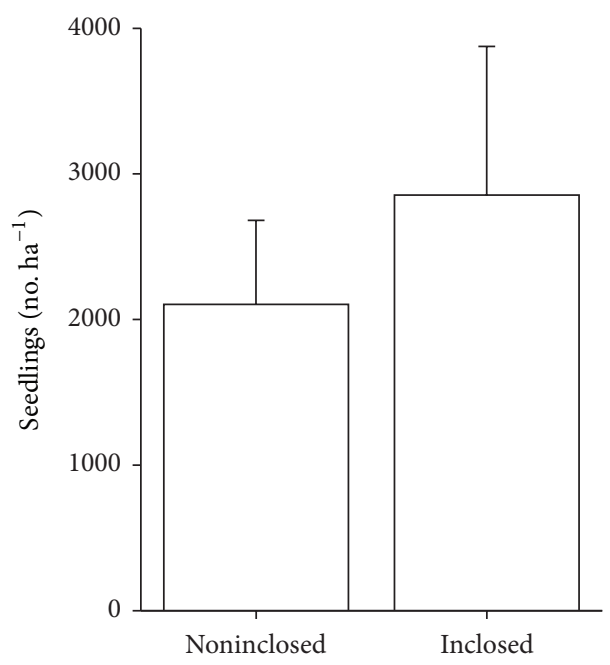

(c)

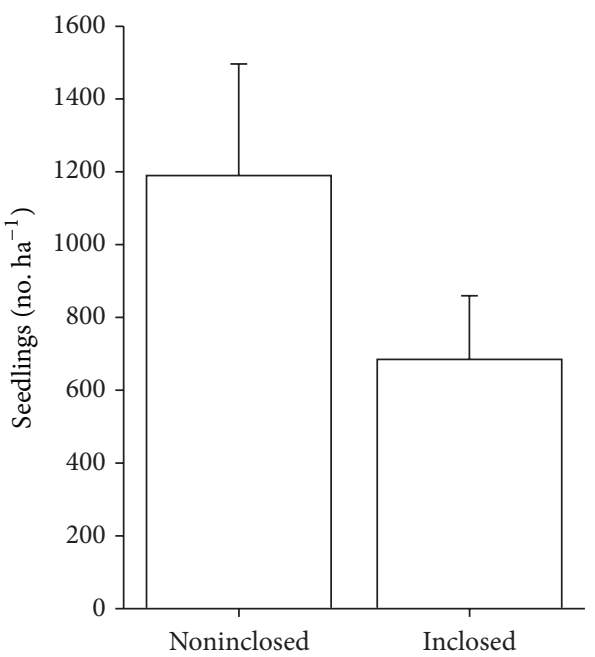

(b)

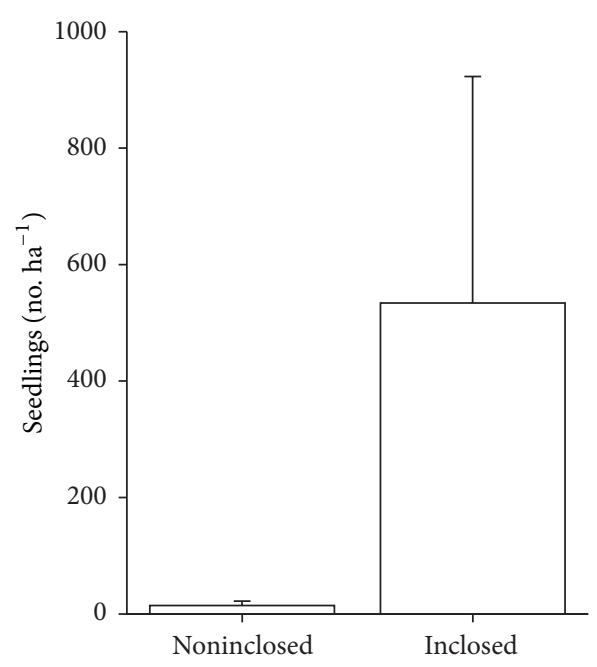

(d)

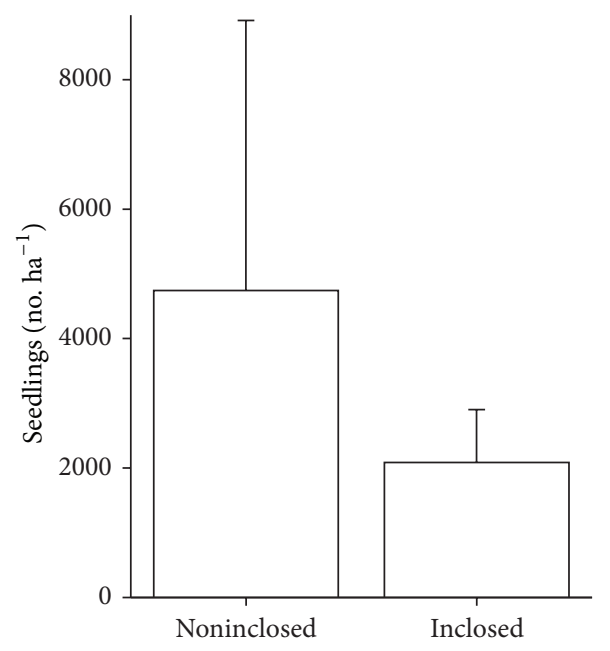

(e)

Figure 3: Seedling densities of selected tree species in the New Forest woodlands, assessed in Survey 1 (see text). Values presented are means $( \pm$ SE). (a) Betula pendula; (b) Fagus sylvatica; (c) Ilex aquifolium; (d) Pinus sylvestris; (e) Quercus robur. 
TABLE 2: List of species encountered in the field survey of grassland and heathland sites (Survey 2) as seedlings and/or saplings. Species that are not considered to be native to the study area are asterisked. Note that "seedlings" and "saplings" of Ulex europea and Calluna vulgaris were not recorded separately in this survey. Ulex europea was present in $52.6 \%$ of grassland plots and $25.8 \%$ of heathland sites, while corresponding values for Calluna vulgaris were $26.3 \%$ and $61.3 \%$, respectively.

\begin{tabular}{|c|c|c|c|c|c|}
\hline \multirow{2}{*}{ Latin name } & \multirow{2}{*}{ English name } & \multicolumn{2}{|c|}{ Grassland sites } & \multicolumn{2}{|c|}{ Heathland sites } \\
\hline & & $\begin{array}{c}\text { Percentage of plots } \\
\text { with seedlings }\end{array}$ & $\begin{array}{l}\text { Percentage of plots } \\
\text { with saplings }\end{array}$ & $\begin{array}{l}\text { Percentage of plots } \\
\text { with seedlings }\end{array}$ & $\begin{array}{c}\text { Percentage of plots } \\
\text { with saplings }\end{array}$ \\
\hline Acer campestre & Field maple & 5.3 & - & - & - \\
\hline Betula pendula & Silver birch & 36.8 & 52.6 & 45.2 & 22.6 \\
\hline Corylus avellana & Hazel & - & - & 3.2 & - \\
\hline Crataegus monogyna & Hawthorn & 5.3 & 31.6 & - & - \\
\hline Fagus sylvatica & Beech & & 5.3 & - & - \\
\hline Frangula alnus & Alder buckthorn & - & 10.5 & 6.5 & 3.2 \\
\hline Ilex aquifolium & Holly & 5.3 & 15.8 & 6.5 & 9.7 \\
\hline${ }^{*}$ Pinus sylvestris & Scots pine & 5.3 & 5.3 & 19.4 & 3.2 \\
\hline Prunus spinosa & Blackthorn & 10.5 & 10.5 & 6.5 & 3.2 \\
\hline Quercus robur & Oak & 15.8 & 10.5 & 22.6 & - \\
\hline Salix cinerea & Grey willow & - & - & - & 3.2 \\
\hline Sorbus aucuparia & Rowan & 10.5 & 10.5 & 6.5 & 3.2 \\
\hline Viburnum opulus & Guelder rose & - & 5.3 & - & - \\
\hline
\end{tabular}

found only in holly $(r=-0.40, P<0.001)$, birch $(r=-0.15$, $P=0.045)$, Scots pine $(r=-0.21, P=0.006)$, and Taxus baccata (yew) $(r=0.23, P=0.002)$.

3.2. Survey 2. In the survey of grassland and heathland areas, seedlings of a total of 13 woody species were encountered in addition to the shrubs gorse and heather, which were both widespread (Table 2). Of these, birch was consistently the most frequent, being present as a sapling on $23 \%$ of heathland sites and $53 \%$ of grassland sites. Oak was also widespread as a seedling, being present on $23 \%$ of heathland sites and $16 \%$ of grassland sites. Spiny shrubs such as hawthorn and blackthorn were more frequent on grassland sites than heathland sites, but both species were less frequent than birch on both types of site.

3.3. Survey 3. A total of ten woody species were observed as saplings and nine as seedlings (Table 3). Again, birch was found to be the most frequent species, occurring on $73 \%$ of plots either as a seedling and/or as a sapling. Hawthorn and blackthorn were present on $27 \%$ and $13 \%$ of plots, respectively, indicating the presence of spiny shrubs that could potentially provide protection from herbivory. However, such putative protection was only observed in a minority of plots and for only two species, namely, $10 \%$ of plots in the case of birch and $3 \%$ in the case of beech.

3.4. Model Testing. Regression analysis indicated a positive relationship between the number of survey plots in which each tree species was predicted to occur by the model and the number of plots in which each species was recorded in Survey $3\left(r^{2}=0.55, P=0.001\right)$. Predicted species richness for the field plots closely approximated that recorded in the field survey (mean \pm SE: $2.7 \pm 0.3$ and $2.2 \pm 0.3$, resp.) and median values were identical (2.5; Mann-Whitney $U$ test, $P=0.34)$. The model correctly predicted presence of eight species in the field plots and correctly predicted the absence of a further 17 species. However, the model also predicted the presence of five species that were not recorded in the field survey (Castanea sativa (sweet chestnut), European black pine, Douglas fir, grey willow, and Sorbus aucuparia (rowan)), although none of these species was predicted to occur in more than $20 \%$ of field plots. The model also failed to predict the presence of three species (beech, ash, and blackthorn) that were encountered in this survey, although none of these occurred in more than $13 \%$ of field plots.

3.5. Scenarios. Over the duration of the simulations ( $300 \mathrm{yr}$ ), woodland area increased in all scenarios, with or without disturbance. The increase in woodland area was most pronounced in Scenario 1 (no disturbance), with an increase of $175 \%$ over the initial value (Figure 4 ). However, woodland area increased by more than $70 \%$ even in Scenario 4 , where disturbance was most intense. The inclusion of protection from herbivory by presence of spiny shrubs (Scenario 5) resulted in larger woodland areas than in the other scenarios where disturbance was present, with an increase of $30 \%$ over the value recorded in Scenario 4. The substantially lower values recorded in Scenario 4 than either Scenario 2 or 3 suggest a positive interaction between the effects of fire and browsing.

Different tree species displayed contrasting patterns of abundance over time (Figure 5). Scots pine, holly, and birch were characterised by an initial increase in extent followed by a subsequent decline, with peak values recorded after 
TABLE 3: (a) List of species encountered in the field survey of woodland expansion (Survey 3) as seedlings and/or saplings. Species that are not considered to be native to the study area are asterisked. (b) Occurrence of protection of seedlings by spiny shrubs, encountered in the field survey of woodland expansion (Survey 3). Species that are not considered to be native to the study area are asterisked.

(a)

\begin{tabular}{llcc}
\hline Latin name & English name & Percentage of plots with saplings & Percentage of plots with seedlings \\
\hline Betula pendula & Silver birch & 43.3 & 53.3 \\
Crataegus monogyna & Hawthorn & 20.0 & 16.7 \\
Fagus sylvatica & Beech & 3.3 & 6.7 \\
Frangula alnus & Alder buckthorn & 3.3 & 3.3 \\
Fraxinus excelsior & Ash & 3.3 & 30.0 \\
Ilex aquifolium & Holly & 23.3 & 10.0 \\
${ }^{*}$ Pinus sylvestris & Scots pine & 10.0 & 6.7 \\
Prunus spinosa & Blackthorn & 6.7 & 33.3 \\
Quercus robur & Oak & & 3.3 \\
Taxus baccata & Yew & 6.7 & 3.3 \\
Ulex europea & Common gorse & & \\
\hline
\end{tabular}

(b)

\begin{tabular}{llcc}
\hline Latin name & English name & $\begin{array}{c}\text { Percentage of plots with seedlings } \\
\text { present, protected by shrubs }\end{array}$ & $\begin{array}{c}\text { Percentage of plots with seedlings } \\
\text { present, not protected by shrubs }\end{array}$ \\
\hline $\begin{array}{l}\text { Betula pendula } \\
\text { Crataegus monogyna }\end{array}$ & Silver birch & 10.0 & 43.3 \\
Fagus sylvatica & Heech & 3.3 & 16.7 \\
Frangula alnus & Alder buckthorn & & 3.3 \\
Ilex aquifolium & Holly & & 3.3 \\
${ }^{*}$ Pinus sylvestris & Scots pine & 30.0 \\
Prunus spinosa & Blackthorn & & 10.0 \\
Quercus robur & Oak & & 6.7 \\
Taxus baccata & Yew & & 33.3 \\
\hline
\end{tabular}

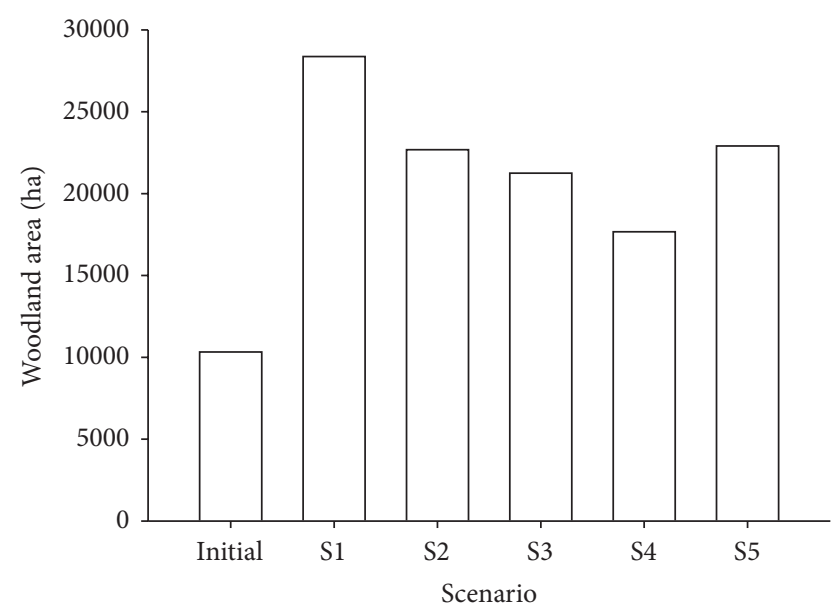

Figure 4: Projected woodland extent under different disturbance regimes. Values presented are the areas (ha) occupied by one or more of the five principal tree species (Betula pendula, Fagus sylvatica, Ilex aquifolium, Pinus sylvestris, and Quercus robur), as individuals $\geq 10$ years old. "Initial" values are those at the onset of model scenarios; the values given under each scenario (S1-5) are those projected to occur after 300 years following the simulations described in the text.
60-90 years in the case of birch, 180-210 years in the case of holly, and 90-180 years in the case of Scots pine, precise values differing between scenarios (Figure 5). In contrast, beech demonstrated a continual increase in extent in all scenarios, which was most pronounced in Scenarios 1 and 5. Oak increased during the initial 30 year interval and thereafter remained relatively constant in extent, with a slight decline recorded after 90-180 years, depending on the scenario. After 300 years, values of oak and beech were higher than initial values in all scenarios, whereas the extent of birch was lower than the initial value in all scenarios. Although the highest final values of beech, oak, and holly were recorded in Scenario 1, the highest final value of birch was recorded in Scenario 5 and that of pine in Scenario 2.

Hypotheses (ii)-(iv) were tested by examining the output maps generated by LANDIS II. These indicated that the pattern of tree colonisation, as hypothesized, tended to occur particularly on the periphery of woodlands, leading to a concentric pattern of woodland expansion. However, this pattern was observed even in Scenario 4, without protection from herbivory by spiny shrubs. This indicates that woodland expansion is projected to occur even in the absence of 


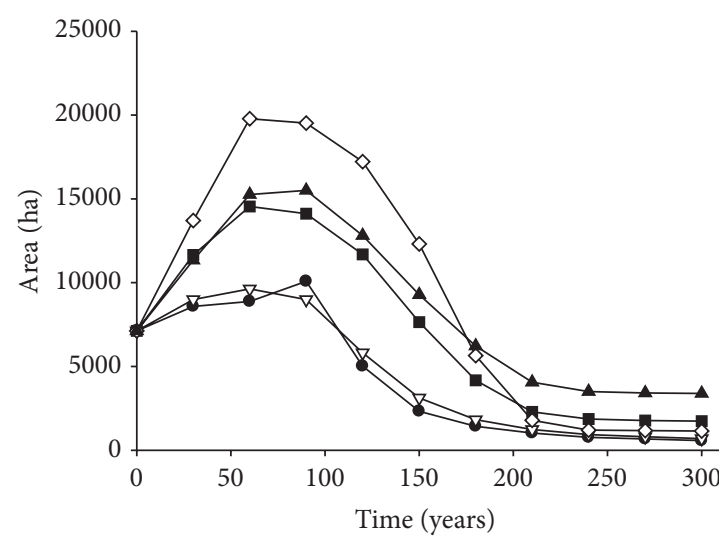

(a)

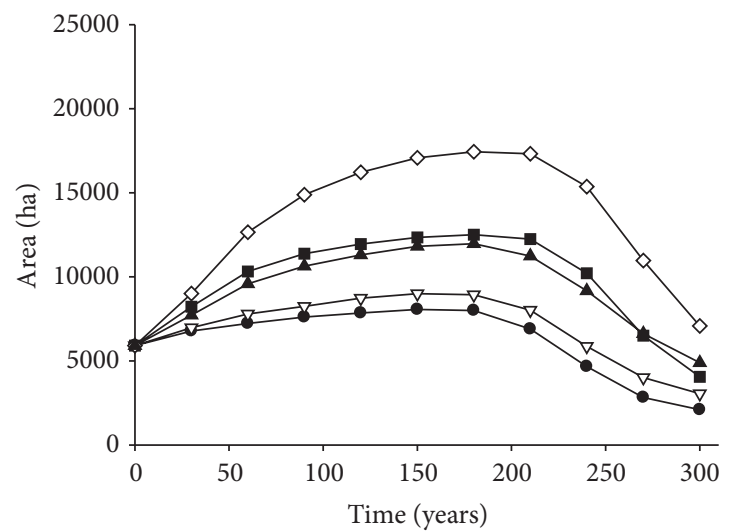

(c)

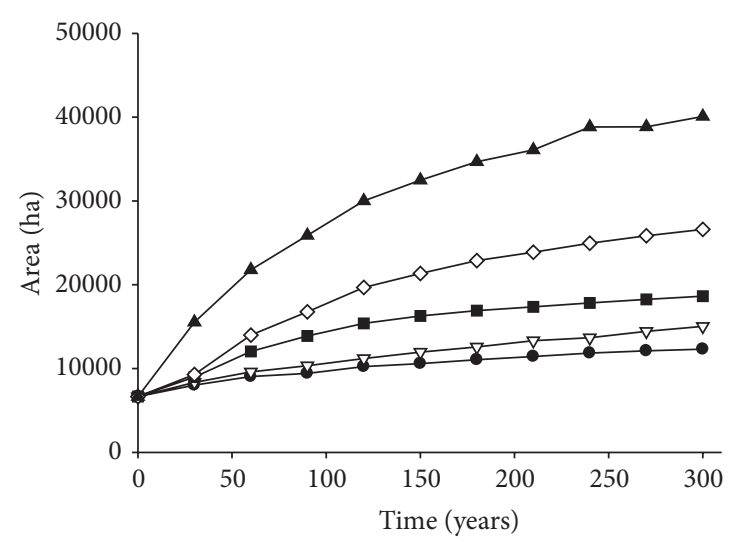

(b)

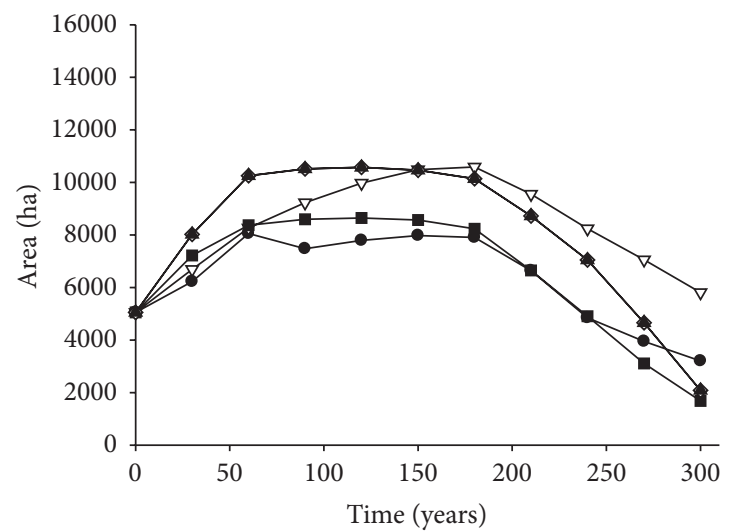

(d)

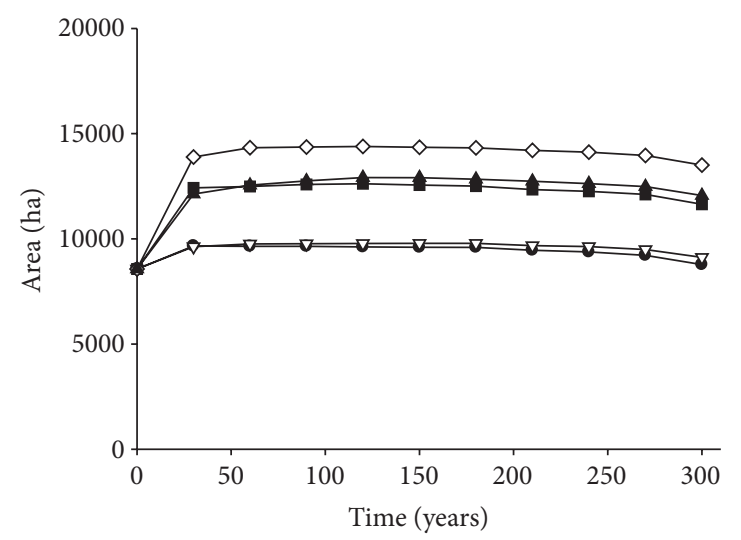

(e)

Figure 5: Projected extent of occurrence ("area") of selected tree species in the New Forest, using the LANDIS II model to explore different disturbance regimes. (a) Betula pendula; (b) Fagus sylvatica; (c) Ilex aquifolium; (d) Pinus sylvestris; (e) Quercus robur. Calculation of the extent of occurrence was based on the occupation of a $50 \times 50 \mathrm{~m}$ site (pixel) by an individual tree of age $\geq 10$ years old. Scenario 1 , empty diamond; scenario 2, empty triangle; scenario 3, filled square; scenario 4, filled circle; scenario 5, filled triangle (see text for details).

facilitation, although to a lesser degree than when facilitation is present. Overall, woodland expansion was observed in all scenarios, with little evidence for the breakup of groves or their conversion to either grassland or heathland. Stands initially dominated by early successional species such as birch and Scots pine became increasingly dominated by beech over time. Evidence for the breakup or conversion of stands was examined by overlaying output maps for Scenario 4 after 300 years on that for time zero. A total of 2,169 $50 \times 50 \mathrm{~m}$ sites (pixels) were found to be woodland at time zero but were not projected to be wooded after 300 years; this contrasts with 39,133 sites that were wooded at both times and 31,550 that were wooded after 300 years but not at the outset. In other words, $5 \%$ of the woodland area present at the outset was 
not associated with woodland at the end of the simulation, in this most disturbed scenario. The corresponding value for Scenario 1 (no disturbance) was $0.2 \%$ (106 sites).

\section{Discussion}

Although large herbivores are now widely employed as a tool for biodiversity conservation management, their use remains controversial [33], particularly as evidence regarding their effectiveness is often lacking [14]. As noted by Gordon et al. [34], the use of large herbivores to achieve conservation management objectives requires an understanding of the relationships between grazing and biodiversity; specifically, managers require information on the potential impacts of different herbivore densities under different conditions. Such information is often difficult to obtain in a systematic manner because of the high cost of appropriate experimental designs and the need for measurement of multiple driving factors, before widely applicable generalizations can be made [34]

As illustrated here, the impacts of herbivory on the spatial dynamics of vegetation can potentially be explored using spatially explicit models. While progress has been made in understanding the influence of landscape pattern on the dynamics and movement of large herbivores, using a variety of different modelling approaches, relatively few models have been developed that can directly inform conservation management [35]. Key challenges to the development of such models include the need to incorporate interactions among multiple animal and plant species, together with landscapescale processes such as plant dispersal, cultural features, and land use change and interactions between herbivory and other forms of disturbance [35]. As demonstrated here, LANDIS II can potentially overcome such challenges, enabling the impacts of herbivory on the spatial dynamics of vegetation to be explored in conjunction with other types of disturbance. LANDIS II also connects strongly with real-world data and can incorporate management activities as driving variables, two other features that are useful for addressing questions relating to conservation management [35]. Other landscapescale models that can be used to explore the role of large herbivores in a management context include SAVANNA [36] and FORSPACE $[37,38]$. SAVANNA differs from LANDIS II in that dispersal of individual plant species is not explicitly simulated, whereas FORSPACE differs in that age structure is treated much more simply; all trees are grouped into a single cohort [35]. However, both models explicitly incorporate energetics to simulate the removal of plant biomass by herbivores, rather than purely plant species and age as employed here.

As with any attempt at ecological modelling, the research described here is subject to a number of uncertainties [10], and these should be borne in mind when interpreting the results. While every attempt was made to ensure accurate parameterization of the model, a degree of uncertainty is inevitable given the lack of appropriate information. For example, it is widely recognized that the dispersal characteristics of many plant species remain poorly defined, particularly at larger scales $[39,40]$. Greater accuracy might be achieved if dispersal measurements for each species were conducted within the study landscape, an approach that was beyond the scope of the current investigation. Other potential disturbance factors that were not considered here include wind disturbance, climate change, and damage by Sciurus caroliniensis (grey squirrel), pests, and pathogens, all of which could be significant causes of tree mortality. Another key assumption was that browsing was assumed to be evenly distributed across the study area, which is likely not to be the case in reality, although accurate information on the spatial distribution of browsing mammals is currently lacking. Information on the browsing preferences of different mammal species within the study area, and the tolerance of different plant species to browsing damage, is also limited. Uncertainties relating to herbivore behaviour and browsing preferences are common to other approaches involving modelling of herbivore impacts on vegetation $[35,41]$. The use of LANDIS II to explore herbivore impacts could potentially be strengthened in future, for example, through integration with individual based models of foraging behaviour [42].

In the New Forest, as in many other conservation areas where large herbivores are present, the identification of appropriate herbivore densities has been highly controversial. The persistence of some species of high conservation value is strongly dependent on maintenance of high herbivore pressure, as in the case of plant species associated with short grassland swards [27]. It is for this reason that recent management plans [43] have placed the maintenance of herbivore populations as a principal objective. However, marked declines in other groups of species, such as Lepidoptera, have been attributed to grazing being excessive [27], a conclusion supported by research into the ecology of large herbivores themselves [32]. Particular concern has focused on the perceived lack of woodland regeneration, which has repeatedly been used as justification for forest management interventions, some of which have resulted in negative environmental impacts $[28,44]$. A number of authors have suggested that regeneration of tree species is severely limited or entirely absent in these woodlands as a result of high herbivore pressure [45-48]. However, these previous observations were based on a limited number of sites. The results of the present study, in what represents the first systematic survey of tree regeneration in all New Forest woodlands, indicate that tree regeneration occurs widely but at low density; for example, oak and beech saplings were recorded on $16 \%$ and $26 \%$ of sites, respectively. This is despite the fact that browsing pressure is uniformly high. While it is widely recognized that large herbivores can substantially reduce tree seedling densities and thereby reduce or eliminate cohorts of young trees [49], in the current study saplings were entirely absent in only $10 \%$ of woodland plots (Survey 1 ), and seedlings were entirely absent in only a single survey plot.

Modelling results projected an increase in forest area under all disturbance regimes, even under high browsing pressure and with management of heathland by rotational burning. The current colonization of grassland and heathland areas by tree species is confirmed by results of Surveys 2 and 3. These results are supported by analyses of historic maps, which indicate that native woodland area increased 
substantially in the New Forest during much of the 20th century [50]. It is for this reason that scrub clearance by cutting also continues to form part of the management of the New Forest, in addition to grazing and burning [43]. The impact of herbivory on the spatial dynamics of vegetation reflects the balance achieved between rates of woodland expansion and collapse, both of which may be highly variable in both space and time [49]. Vera's theory [16], relating to the cyclic dynamics of vegetation, depends critically on the breakup of woodland groves with maturity and their conversion to either grassland or heathland. Modelling results provided very little support for this phenomenon. Rather, the results indicated the progressive dominance of beech and an associated decline of relatively shade-intolerant species such as birch and Scots pine, through a process of competitive exclusion. This same general trend was observed in all disturbance regimes, although differing in rate between them. Increasing dominance of the more shade-tolerant beech is consistent with traditional successional theory [51] and is also supported by historical observations in the New Forest [50]. In addition, palaeoecological analyses have shown marked increases in the amount of beech pollen in the area over the past 500 years [52]. At the landscape scale, model projections indicated progressive expansion and coalescence of woodland areas even under high herbivore pressure, in contrast to the shifting mosaic of woodland and nonwoodland vegetation hypothesized by Vera [16]. Model exploration during calibration indicated that browsing pressures high enough to largely prevent regeneration within woodlands also prevented woodland expansion, which was inconsistent with field observations.

A further key element of Vera's theory [16] is the role of facilitation, involving the protection of tree seedlings from herbivory by spiny shrubs. Results from Surveys 2 and 3 provided some support for this hypothesis, indicated by the association of young trees with spiny shrubs, but also provided evidence of widespread colonization of both heathland and grassland sites by a range of tree species (especially birch) without such facilitation. This suggests that tree regeneration is neither restricted to the periphery of woodlands nor sites where spiny shrubs are present. These results can be compared with those of Bakker et al. [25], who reported a positive association between spiny shrubs and oak in the New Forest; however, this association was significant only for mature trees ( $>2 \mathrm{~m}$ height and mostly $>10 \mathrm{~cm} \mathrm{dbh}$ ), and observations were restricted to a single site. The model simulations indicated that facilitation could potentially have a substantial effect on the relative abundance of individual tree species and on total woodland extent, the latter increasing by $30 \%$ over a 300 year interval as a result (Scenarios 4 versus 5, Figure 4). However, facilitation had relatively little impact on the pattern of woodland development; expansion from woodland margins was projected even in the absence of facilitation.

These results question whether it is appropriate to base conservation management plans on Vera's theory, which is currently the case in the New Forest [44], as in many other locations. Further research is required on the role of herbivory in woodland collapse and the quantitative importance of facilitation, in order to define with greater precision the situations under which Vera's theory is likely to apply. Such conditions might prevail under higher herbivore densities than those currently being experienced in the New Forest (approximately 1.9 animals ha ${ }^{-1}$ [25]), although current densities are historically at an exceptionally high value $[27,28]$.

\section{Conclusions}

As illustrated here, spatially explicit modelling approaches can potentially be of value in exploring the potential impacts of different conservation management options, including manipulation of herbivore pressure, and for identifying the appropriate location of interventions, such as the cutting or burning of vegetation. Modelling results also provide some insight into the potential long-term implications of high herbivore pressure on the structure and composition of vegetation, as well as its spatial pattern. One of the characteristics of the New Forest, examined here, is that a range of different habitats of high conservation value occur together in an intimate successional mosaic. In such locations, the contrasting requirements of different habitats may create potential management conflicts. For example, while high herbivore pressure is widely viewed as essential for maintenance of successional habitats such as heathland and grassland, in the New Forest this has created concerns about the impacts of herbivory on adjacent woodlands. The current results suggest that such conflicts can potentially be reconciled, as woodland regeneration was projected to occur even under high herbivore pressure. However, successional habitats may require active vegetation management such as cutting and burning, in addition to grazing, for succession to woodland to be prevented.

\section{Conflict of Interests}

This is to confirm that none of the authors have a direct financial relation with any of the commercial identities mentioned in this paper that might lead to a conflict of interests.

\section{Acknowledgments}

Thanks to Andrew Brown, Richard Reeves (New Forest Centre), Ed Mountford (JNCC), Jonathan Spencer, Berry Stone, and Simon Weymouth (Forestry Commission) for assistance with the research.

\section{References}

[1] D. Lindenmayer, R. J. Hobbs, R. Montague-Drake et al., "A checklist for ecological management of landscapes for conservation," Ecology Letters, vol. 11, no. 1, pp. 78-91, 2008.

[2] S. T. A. Pickett and P. S. White, Eds., The Ecology of Natural Disturbance and Patch Dynamics, Academic Press, New York, NY, USA, 1985.

[3] W. J. Sutherland, The Conservation Handbook, Research, Management and Policy, Blackwell Science, Oxford, UK, 2000. 
[4] A. C. Newton, C. Echeverría, E. Cantarello, and G. Bolados, "Projecting impacts of human disturbances to inform conservation planning and management in a dryland forest landscape," Biological Conservation, vol. 144, no. 7, pp. 1949-1960, 2011.

[5] M. Uriarte, C. D. Canham, J. Thompson et al., "Natural disturbance and human land use as determinants of tropical forest dynamics: results from a forest simulator," Ecological Monographs, vol. 79, no. 3, pp. 423-443, 2009.

[6] W. J. Sutherland, "Predicting the ecological consequences of environmental change: a review of the methods," Journal of Applied Ecology, vol. 43, no. 4, pp. 599-616, 2006.

[7] D. B. Lindenmayer and J. F. Franklin, Conserving Forest Biodiversity, A Comprehensive Multiscaled Approach, Island Press, Washington, DC, USA, 2002.

[8] H. Bugmann, "A review of forest gap models," Climatic Change, vol. 51, no. 3-4, pp. 259-305, 2001.

[9] A. Porté and H. H. Bartelink, "Modelling mixed forest growth: a review of models for forest management," Ecological Modelling, vol. 150, no. 1-2, pp. 141-188, 2002.

[10] A. C. Newton, Forest Ecology and Conservation. A Handbook of Techniques, Oxford University Press, Oxford, UK, 2007.

[11] D. J. Mladenoff, "LANDIS and forest landscape models," Ecological Modelling, vol. 180, no. 1, pp. 7-19, 2004.

[12] R. M. Scheller, J. B. Domingo, B. R. Sturtevant et al., "Design, development, and application of LANDIS-II, a spatial landscape simulation model with flexible temporal and spatial resolution," Ecological Modelling, vol. 201, no. 3-4, pp. 409-419, 2007.

[13] W. Spencer, H. Rustigian-Romsos, J. Strittholt, R. Scheller, W. Zielinski, and R. Truex, "Using occupancy and population models to assess habitat conservation opportunities for an isolated carnivore population," Biological Conservation, vol. 144, no. 2, pp. 788-803, 2011.

[14] A. C. Newton, G. B. Stewart, G. Myers et al., "Impacts of grazing on lowland heathland in north-west Europe," Biological Conservation, vol. 142, no. 5, pp. 935-947, 2009.

[15] K. H. Hodder and J. M. Bullock, "Really wild? Naturalistic grazing in modern landscapes," British Wildlife, vol. 20, no. 5, pp. 37-43, 2009.

[16] F. W. M. Vera, Grazing Ecology and Forest History, CABI Publishing, Wallingford, UK, 2000.

[17] F. W. M. Vera, "Large-scale nature development-the Oostvaardersplassen," British Wildlife, pp. 28-36, 2009.

[18] K. H. Hodder, J. M. Bullock, P. C. Buckland, and K. J. Kirby, "Large herbivores in the wildwood and modern naturalistic grazing systems," English Nature Research Reports 648, English Nature, Peterborough, UK, 2005.

[19] P. Taylor, "Re-wilding the grazers: obstacles to the "wild" in wildlife management," British Wildlife, pp. 50-55, 2009.

[20] M. Galetti, "Parks of the Pleistocene: recreating the cerrado and the Pantanal with megafauna," Natureza e Conservação, vol. 2, no. 1, pp. 93-100, 2004.

[21] D. R. Rubenstein, D. I. Rubenstein, P. W. Sherman, and T. A. Gavin, "Pleistocene Park: does re-wilding North America represent sound conservation for the 21st century?" Biological Conservation, vol. 132, no. 2, pp. 232-238, 2006.

[22] K. J. Kirby, "A model of a natural wooded landscape in Britain as influenced by large herbivore activity," Forestry, vol. 77, no. 5, pp. 405-420, 2004.

[23] F. J. G. Mitchell, "How open were European primeval forests? Hypothesis testing using palaeoecological data," Journal of Ecology, vol. 93, no. 1, pp. 168-177, 2005.
[24] H. Olff, F. W. M. Vera, J. Bokdam et al., "Shifting mosaics in grazed woodlands driven by the alternation of plant facilitation and competition," Plant Biology, vol. 1, no. 2, pp. 127-137, 1999.

[25] E. S. Bakker, H. Olff, C. Vandenberghe et al., "Ecological anachronisms in the recruitment of temperate light-demanding tree species in wooded pastures," Journal of Applied Ecology, vol. 41, no. 3, pp. 571-582, 2004.

[26] T. Fukami and D. A. Wardle, "Long-term ecological dynamics: reciprocal insights from natural and anthropogenic gradients," Proceedings of the Royal Society B, vol. 272, no. 1577, pp. 21052115, 2005.

[27] A. C. Newton, Ed., Biodiversity in the New Forest, Pisces, Newbury Park, Calif, USA, 2010.

[28] A. C. Newton, "Social-ecological resilience and biodiversity conservation in a 900-year-old protected area," Ecology and Society, vol. 16, no. 4, article 13, 2011.

[29] F. Reimoser, H. Armstrong, and R. Suchant, "Measuring forest damage of ungulates: what should be considered," Forest Ecology and Management, vol. 120, no. 1-3, pp. 47-58, 1999.

[30] D. Ray, Ecological Site Classification, a PC-Based Decision Support System for British Forests, Users Guide, Forestry Commission, Edinburgh, UK, 2001.

[31] A. D. Syphard, J. Yang, J. Franklin, H. S. He, and J. E. Keeley, "Calibrating a forest landscape model to simulate frequent fire in Mediterranean-type shrublands," Environmental Modelling and Software, vol. 22, no. 11, pp. 1641-1653, 2007.

[32] R. J. Putman, Grazing in Temperate Ecosystems, Large Herbivores and their Effects on the Ecology of the New Forest, Croom Helm/Chapman and Hall, London, UK, 1986.

[33] M. F. Wallis De Vries, J. P. Bakker, and S. E. Van Wieren, Eds., Grazing and Conservation Management, Kluwer Academic, Dordrecht, The Netherlands, 1998.

[34] I. J. Gordon, A. J. Hester, and M. Festa-Bianchet, “The management of wild large herbivores to meet economic, conservation and environmental objectives," Journal of Applied Ecology, vol. 41, no. 6, pp. 1021-1031, 2004.

[35] P. J. Weisberg, M. B. Coughenour, and H. Bugmann, "Modelling of large herbivore-vegetation interactions in a landscape context," in Large Herbivore Ecology, Ecosystem Dynamics and Conservation, K. Danell, P. Duncan, R. Bergström, and J. Pastor, Eds., pp. 348-382, Cambridge University Press, Cambridge, UK, 2006.

[36] P. J. Weisberg and M. B. Coughenour, "Model-based assessment of aspen responses to Elk herbivory in rocky mountain national park, USA," Environmental Management, vol. 32, no. 1, pp. 152169, 2003.

[37] K. Kramer, J. M. Baveco, R. J. Bijlsma et al., "Landscape forming processes and diversity of forested landscapes-description and application of the model FORSPACE," Alterra Report 216, Wageningen, The Netherlands, 2001.

[38] K. Kramer, G. W. T. A. Groot Bruinderink, and H. H. T. Prins, "Spatial interactions between ungulate herbivory and forest management," Forest Ecology and Management, vol. 226, no. 1-3, pp. 238-247, 2006.

[39] D. F. Greene and C. Calogeropoulos, "Measuring and modelling seed dispersal of terrestrial plants," in Dispersal Ecology, J. M. Bullock, R. E. Kenward, and R. S. Hails, Eds., pp. 3-23, Blackwell, Oxford, UK, 2002.

[40] P. Vittoz and R. Engler, "Seed dispersal distances: a typology based on dispersal modes and plant traits," Botanica Helvetica, vol. 117, no. 2, pp. 109-124, 2007. 
[41] P. J. Weisberg and H. Bugmann, "Forest dynamics and ungulate herbivory: from leaf to landscape," Forest Ecology and Management, vol. 181, no. 1-2, pp. 1-12, 2003.

[42] R. A. Stillman, "MORPH-An individual-based model to predict the effect of environmental change on foraging animal populations," Ecological Modelling, vol. 216, no. 3-4, pp. 265-276, 2008.

[43] R. N. Wright and D. V. Westerhoff, New Forest SAC Management Plan, English Nature, Lyndhurst, NJ, USA, 2001.

[44] A. C. Newton, E. Cantarello, G. Myers, S. Douglas, and N. Tejedor, "The condition and dynamics of New Forest woodlands," in Biodiversity in the New Forest, A. C. Newton, Ed., pp. 132-147, Pisces, Newbury Park, Calif, USA, 2010.

[45] G. F. Peterken and C. R. Tubbs, "Woodland regeneration in the New Forest, Hampshire, Since 1650," Journal of Applied Ecology, vol. 2, no. 1, pp. 159-170, 1965.

[46] R. J. Putman, R. M. Pratt, J. R. Ekins, and P. J. Edwards, "Food and feeding behaviour of cattle and ponies in the New Forest, Hampshire," Journal of Applied Ecology, vol. 24, no. 2, pp. 369380, 1987.

[47] E. P. Mountford and G. F. Peterken, "Long-term change and implications for the management of wood-pastures: experience over 40 years from Denny Wood, New Forest," Forestry, vol. 76, no. 1, pp. 19-40, 2003.

[48] E. P. Mountford, G. F. Peterken, P. J. Edwards, and J. G. Manners, "Long-term change in growth, mortality and regeneration of trees in Denny Wood, an old-growth wood-pasture in the New Forest (UK)," Perspectives in Plant Ecology, Evolution and Systematics, vol. 2, no. 2, pp. 223-272, 1999.

[49] R. M. A. Gill, "The influence of large herbivores on tree recruitment and forest dynamics," in Large Herbivore Ecology, Ecosystem Dynamics and Conservation, K. Danell, P. Duncan, R. Bergström, and J. Pastor, Eds., pp. 170-202, Cambridge University Press, Cambridge, UK, 2006.

[50] C. R. Tubbs, The New Forest: History, Ecology and Conservation, New Forest Ninth Century Trust, Lyndhurst, NJ, USA, 2001.

[51] H. Ellenberg, Vegetation Ecology of Central Europe, Cambridge University Press, Cambridge, UK, 4th edition, 1988.

[52] M. J. Grant and M. E. Edwards, "Conserving idealized landscapes: past history, public perception and future management in the New Forest (UK)," Vegetation History and Archaeobotany, vol. 17, no. 5, pp. 551-562, 2008.

[53] CAB International, Forestry Compendium, CAB International, Wallingford, UK, 2003.

[54] M. O. Hill, C. D. Preston, and D. B. Roy, PLANTATT, Attributes of British and Irish Plants: Status, Size, Life History, Geography and Habitats For Use in Connection With the New Atlas of the British and Irish Flora, Centre for Ecology and Hydrology, Peterborough, UK, 2004.

[55] O. Johnson and D. More, Tree Guide, Harper, Collins, London, UK, 2004.

[56] A. Mitchell, Trees of Britain and Northern Europe, Harper Collins, London, UK, 1978.

[57] U. Niinemets and F. Valladares, "Tolerance to shade, drought, and waterlogging of temperate northern hemisphere trees and shrubs," Ecological Monographs, vol. 76, no. 4, pp. 521-547, 2006.

[58] P. Thomas, Trees: Their Natural History, Cambridge University Press, Cambridge, UK, 2000.

[59] R. M. A. Gill, "A review of damage by mammals in north temperate forests: 1. Deer," Forestry, vol. 65, no. 2, pp. 145-169, 1992.
[60] R. M. A. Gill, The Impact of Deer on Woodland Biodiversity, vol. 36 of Information Note, Forestry Commission, Edinburgh, Scotland, 2000.

[61] R. M. A. Gill and V. Beardall, "The impact of deer on woodlands: the effects of browsing and seed dispersal on vegetation structure and composition," Forestry, vol. 74, no. 3, pp. 209-218, 2001.

[62] R. Harmer, A. Kiewitt, G. Morgan, and R. Gill, "Does the development of bramble (Rubus fruticosus L. agg.) facilitate the growth and establishment of tree seedlings in woodlands by reducing deer browsing damage?" Forestry, vol. 83, no. 1, pp. 93102, 2010.

[63] R. J. Putman, Competition and Resource Partitioning in Temperate Ungulate Assemblies, Chapman and Hall, London, UK, 1996.

[64] R. J. Putman, P. J. Edwards, J. C. E. Mann, R. C. How, and S. D. Hill, "Vegetational and faunal changes in an area of heavily grazed woodland following relief of grazing," Biological Conservation, vol. 47, no. 1, pp. 13-32, 1989.

[65] A. F. M. Van Hees, A. T. Kuiters, and P. A. Slim, "Growth and development of silver birch, pedunculate oak and beech as affected by deer browsing," Forest Ecology and Management, vol. 88, no. 1-2, pp. 55-63, 1996. 

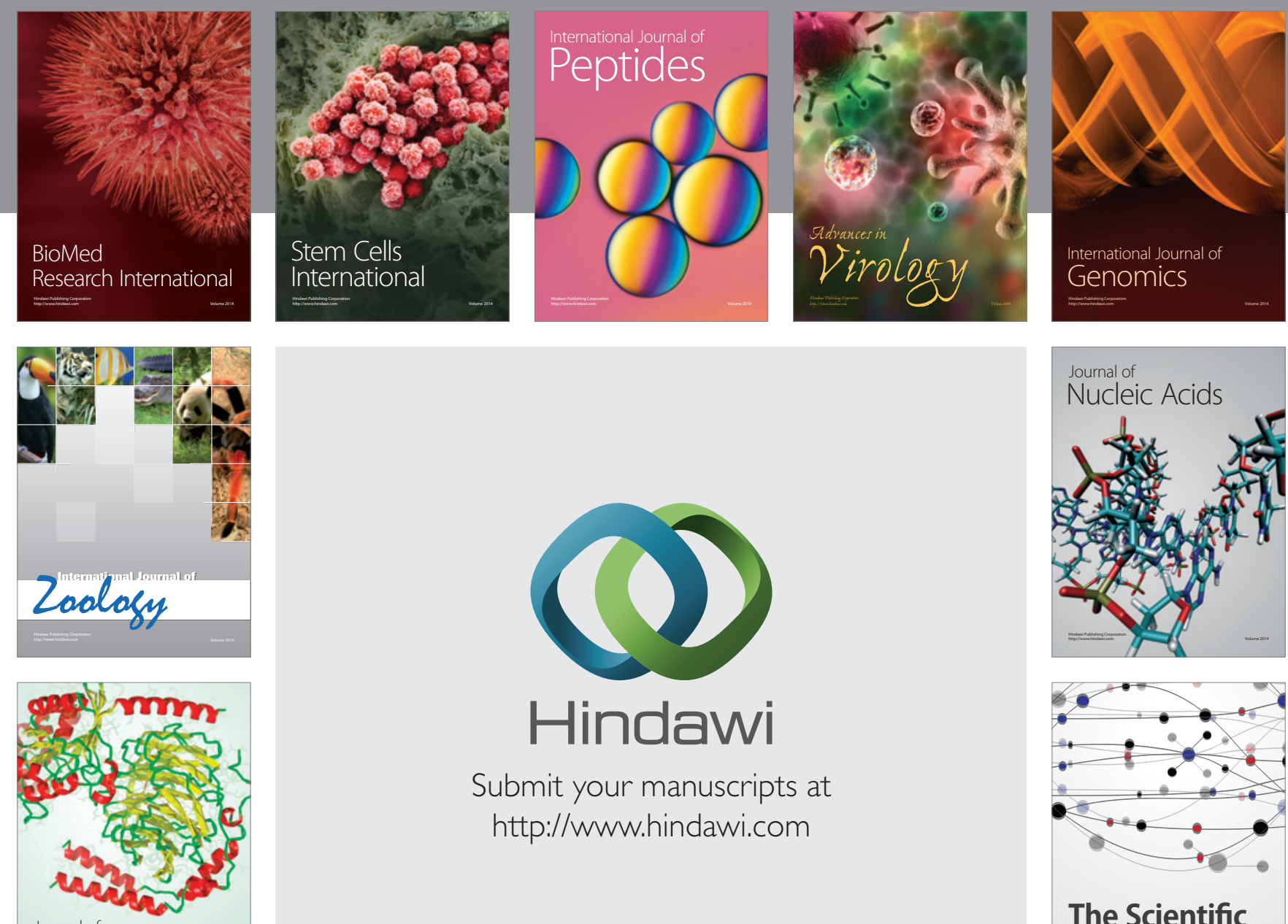

Submit your manuscripts at

http://www.hindawi.com

Journal of
Signal Transduction
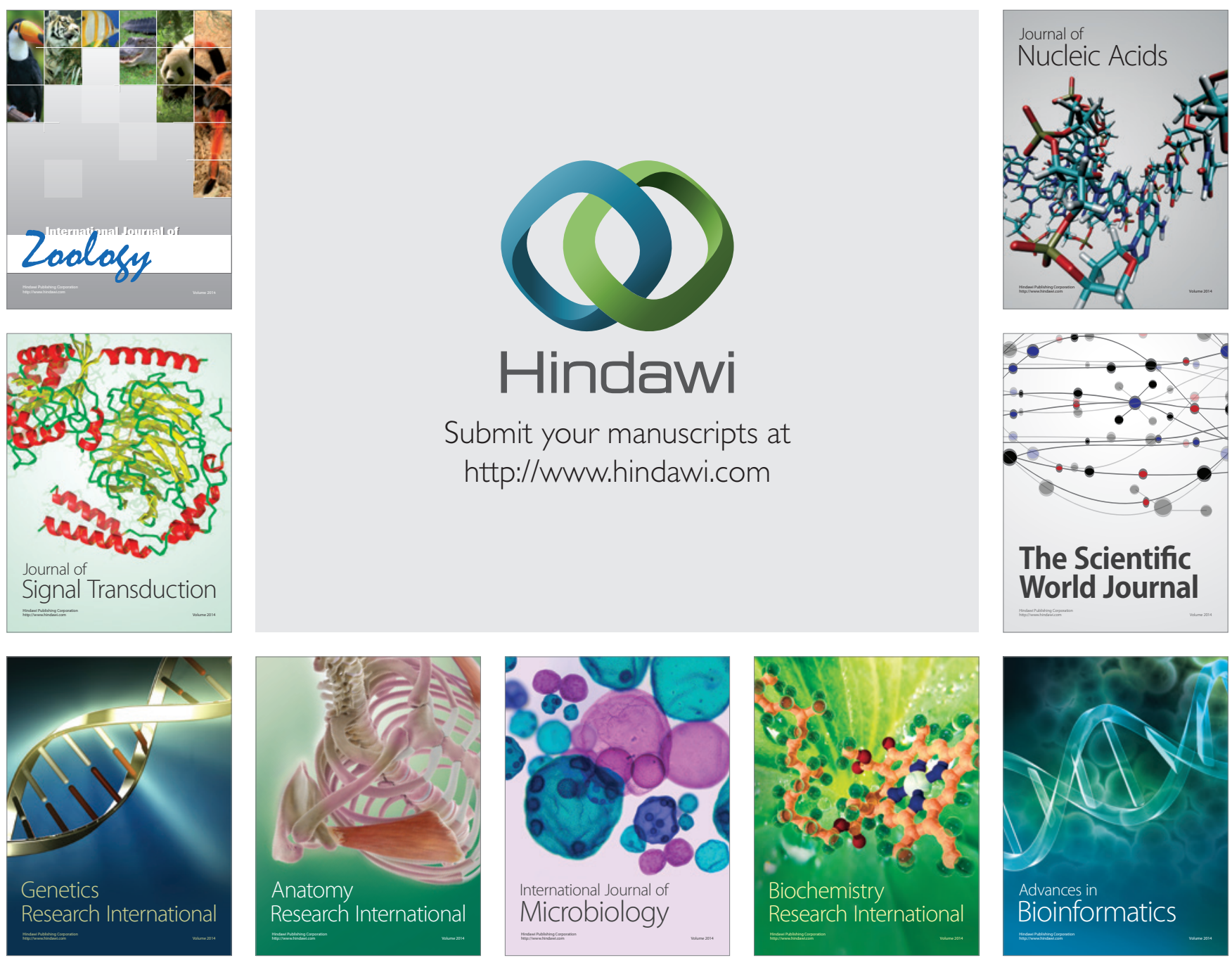

The Scientific World Journal
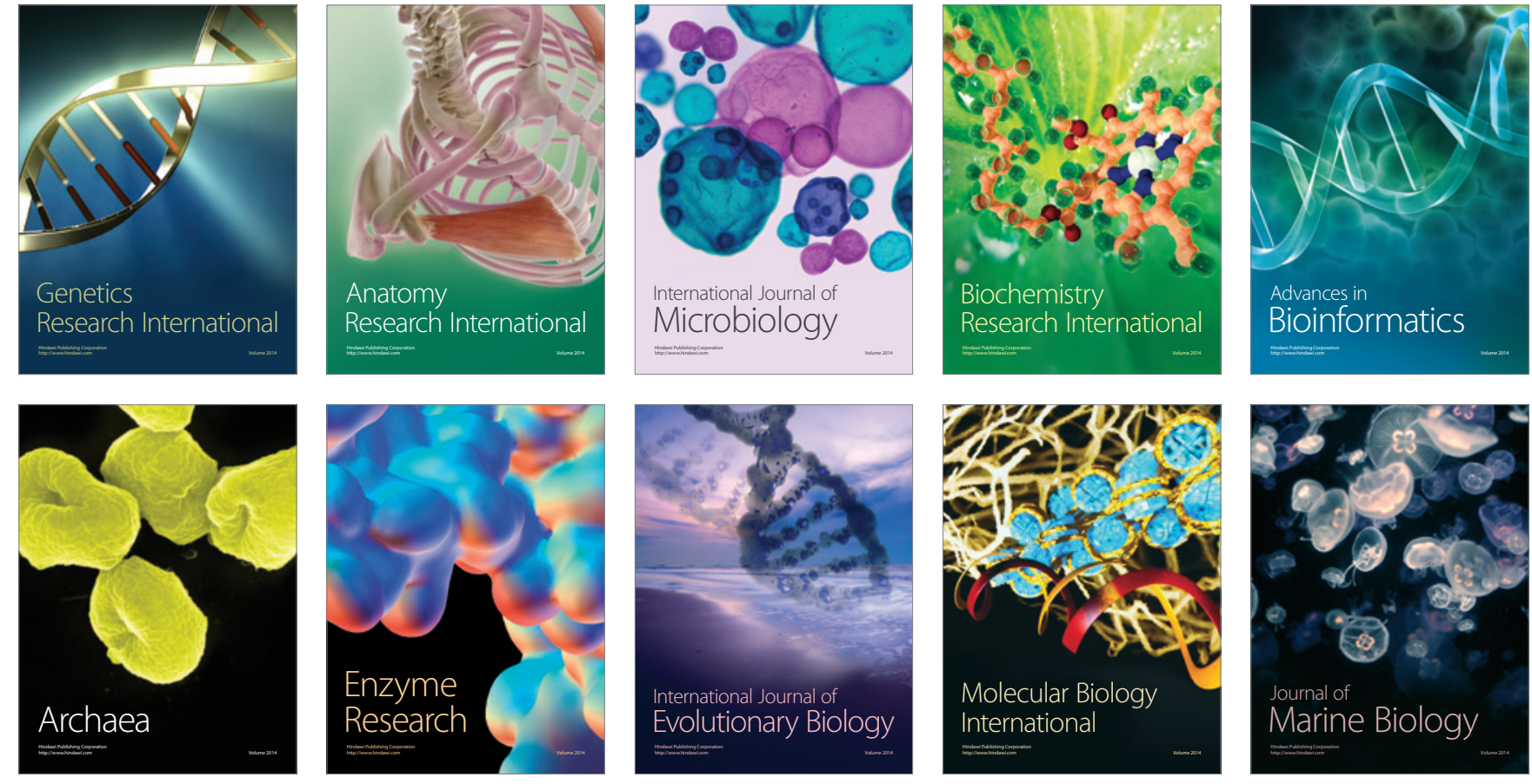